\title{
REPRESENTASI CINTA PADA ALLAH \\ DALAM SYAIR RABI'AH AL-ADAWIYAH DAN SYAIR HUSAIN \\ MANSHUR AL-HALLAJ \\ (Kajian Sastra Bandingan)
}

Tati Nurhayati

\begin{abstract}
This article aims to examine and describe the representation love for God in the poems both of Rabi'ah al-Adawiyah and al-Hallaj. This study is a comparative literature study, in order to find the relation between the two poems. The method used in this study is descriptive analysis method and comparative method. The results of this study show the meaning of Rabi'ah al-Adawiyah's love poems and al-Hallaj's love poems. Then it was found that there was a relation between similarities or similarities in terms of the main meanings both of poems, there were also differences in terms of certain meanings and in terms of the style of presentation.
\end{abstract}

Key word: Representation of Love in Allah, Rabi'ah al-Adawiyah's poems, al-Hallaj's poems.

\begin{abstract}
Abstrak
Artikel ini bertujuan untuk mengkaji dan memaparkan mengenai representasi cinta pada Allah dalam syair Rabi'ah al-Adawiyah dan syair alHallaj. Kajian ini merupakan kajian sastra banding, guna menemukan keterkaitan antara kedua syair tersebut. Metode yang digunakan dalam kajian ini adalah metode deskriptif analisis dan metode komparatif. Hasil dari penelitian ini menunjukkan makna dalam syair cinta Rabi'ah al-

Adawiyah dan syair cinta al-Hallaj. Kemudian ditemukan adanya keterkaitan kemiripan atau persamaan dalam segi makna pokok kedua syair tersebut, juga terdapat perbedaan pada segi makna tertentu dan dari segi gaya penyajiannya.
\end{abstract}

Kata Kunci:Representasi Cinta Pada Allah, Syair Rabi'ah alAdawiyah,Syair al-Hallaj.

\section{A. Pendahuluan}

Cinta ${ }^{1}$ merupakan sesuatu yang selalu menjadi bahasan menarik dalam sepanjang kehidupan manusia, tanpa mengenal golongan, bahkan terkait erat

\footnotetext{
${ }^{1}$ Cinta dalam bahasa Arabdisebut $a l-h u b b$ atau al-mahabbah berasal dari kata habbahubban-hibban yang bermakna waddahu, berarti kasih atau mengasihi. Lihat Louis Ma'luf, alMunjid fi al-Lughah wa al-A 'lam, (Beirut: Dar al-Masyriq, 1973), hlm. 113.
} 
dengan berbagai kalangan, salahsatunya di kalangan kaum sufi. Pembahasan mengenai cinta atau mahabbah di kalangan kaum sufi merupakan salah satu bahasan yang sangat penting, karna terkait dengan mahabbah atau cinta pada Sang Pencipta.

Menurut ahli tasawuf, cinta meliputi ilham, pancaran, dan luapan-luapan hati, cinta dengan perasaan dan segala keberadaannya, maka cinta itu tidak dapat diberi batasan, tidak dapat didefinisikan, dan tidak dapat dijelaskan hakikat dan rahasianya. ${ }^{2}$ Musthafa al-Maraghi memberikan pengertian kata cinta pada kalimat yaitu cinta yang dikhususkan kepada Allah tanpa mempersekutukan cinta itu pada selain Allah. ${ }^{3}$

Beberapa tokoh sufi telah mendefinisikan cinta dengan pemaknaan yang berbeda-beda,seperti Al-Ghazali mengartikan cinta sebagai suatu kecondongannaluri kepada sesuatu yang menyenangkan. ${ }^{4} \mathrm{Al}-J u n a i d$ mengartikan cinta adalah kecenderungan hati, yakni hati cenderunng kepada Tuhan dan apa yang berhubungan dengan Tuhan tanpa dipaksa. ${ }^{5}$ Adapun Jalal al-Din al-Rumi mengatakan bahwa cinta ibarat orang kaya yang tidak mau terhina dan tak silau oleh kekuasaan. Barangsiapa pernah mencicipi sekali saja, ia akan merasakan nikmatnya yang tiada tara. 6

Pembahasan mengenai cinta kepada Sang Pencipta kerap kali dituangkan oleh kaum sufi dalam bait-bait syair. Sebagaimana menurut pandangan bangsa Arab, puisi/syair dianggap sebagai puncak keindahan dalam karya sastra, sebab puisi merupakan bentuk gubahan yang dihasilkan dari kehalusan perasaan dan keindahan imajinasi. Oleh sebab itu, bangsa Arab lebih menyukai puisi daripada karya sastra lainnya. ${ }^{7}$

Seperti salah satu tokoh sufi yang terkenal dengan pemikiran mengenai mahabbah-nya dalam syair-syairnya yaitu Rabi'ah al-Adawiyah. Selain Rabi'ah al- Adawiyah, juga terdapat tokoh-tokoh sufi lainnya yang menuangkan pemikiran mengenai cinta pada Allah, yaitu Husain Manshur al Hallaj. Kedua tokoh sufi tersebut menggambarkan konsep cinta pada Allah dalam syair-syairnya. Sehingga antara syair kedua tokoh tersebut kerap terdapat kemiripan, meskipun pasti ada perbedaannyapula.

Untuk mengupas makna dan keterkaitan antara syair kedua tokoh sufi tersebut mengenai konsep cinta pada Allah, maka diperlukan adanya kajian sastra bandingan, guna mencari titik keterpengaruhan atau keterkaitan antara kedua syair tersebut, perbedaan dan persamaannya, baik dari segi makna, gagasan, maupun

\footnotetext{
${ }^{2}$ Halim Rofi'ie, Cinta Ilahi: Menurut Al-Ghazali dan Rabi'ah Al-Adawiyah, (Jakarta: PT.RajaGrafindo Persada, 2000), hlm. 95.

${ }^{3}$ Ahmad Mustafa al-Maraghi, Tafsir al-Maraghi, juz 1, (Mesir: Mustafa al-Babi al-Halabi wa Auladuh, $1382 \mathrm{H} / 1962 \mathrm{M})$, hlm. 39.

${ }^{4}$ Al-Ghazali, Ihya 'Ulum ad-Din, Juz IV, (Indonesia: Dar Ihya al-Kutub al-“arabiyyah, t.t.), hlm, 288 .

${ }^{5}$ Al-Kalabazi, Ajaran Kaum Sufi, terj. Rahmani Astuti, (Bandung: Mizan, 1990), hlm. 137.

${ }^{6}$ Halim Rofi'ie, Cinta Ilahi: Menurut Al-Ghazali dan Rabi'ah Al-Adawiyah..., hlm. 99.

${ }^{7}$ Yunus ali muhdar \& Bey Arifin, Sejarah Kesusastraan Arab (Surabaya : PT Bina Ilmu, 1983), hlm. 28.
} 
gaya penyajiannya. Pengkajian sastra bandingan adalah ilmu sastra lanjut. Setiap pemerhati sastra, termasuk kritikus, pada saatnya akan berkecimpung dengan pengkajian sastra bandingan. Bagi pemerhati sastra yang telah belajar karya sastra lebih memadai, kiranya pengkajian sastra bandingan memang sebuah keharusan. Rasa ingin tahu dan ingin segera mengupas tuntas persilangan antar sastra, jelas menantang pemerhati sastra. ${ }^{8}$

Kasim mengatakan bahwa bidang penelitian sastra bandingan amat luas; tiap peneliti boleh membandingkan unsur apa saja yang memiliki kemiripan. Adapun bidang-bidang pokok yang menjadi titik perhatian dalam penelitian sastra bandingan di antaranya adalah tema dan motif, genre dan bentuk, aliran dan angkatan, hubungan karya sastra dengan ilmu pengetahuan, agama/kepercayaan, dan karya-karya seni, juga teori sastra, sejarah sastra, dan teori kritik sastra. ${ }^{9}$ Maka dalam artikel ini, yang menjadi titik temu kajian antara kedua syair dari kedua sufi tersebut adalah dalam segi tema, yaitu mengenai representasi cinta pada Allah.

Berdasarkan uraian tersebut, maka dalam artikel ini akan mengkaji satu permasalahan, yaitu representasi cinta pada Allah dalam syair Rabi'ah alAdawiyah dan syair al-Hallaj dengan menggunakan pendekatan sastra bandingan.

\section{B. Metode Penelitian}

Metode yang digunakan dalam penelitian ini adalah metode deskriptif analisis dan metode komparatif. Metode deskriptif analisis dilakukan dengan cara mendeskripsikan fakta-fakta, menguraikan, memberi pemahaman serta penjelasan, yang kemudian dilakukan analisis. ${ }^{10}$ Metode ini digunakan untuk mendeskripsikan dan menganalisis konsep cinta pada Allah dalam syair Rabi'ah al-Adawiyah dan al-Hallaj.

Adapun metode komparatif adalah usaha untuk membandingkan sifat hakiki dalam objek penelitian sehingga dapat ditemukan secara jelas tentang persamaan dan perbedaan. ${ }^{11}$ Metode ini digunakan untuk mengetahui keterkaitan persamaan dan perbedaan antara konsep cinta pada Allah dalam syair Rabi'ah al-Adawiyah dan al-Hallaj.

Maka berdasarkan penggunaan dua metode tersebut, maka tahap pertama dalam penelitian ini akan dilakukan deskripsi dan analisis terhadap konsep cinta pada Allah dalam syair Rabi'ah al-Adawiyah dan al-Hallaj. Setelah itu, keduanya dibandingkan guna menemukan keterkaitan persamaan maupun perbedaannya.

8 Suwardi Endraswara, Sastra Bandingan: Metode, Teori, dan aplikasi, (Yogyakarta: Universitas Negeri Yogyakarta, 2010), hlm. 1.

${ }^{9}$ Suwardi Endraswara, Metode Penelitian Sastra Bandingan, (Jakarta: bukupop, 2011), hlm. 81 .

${ }^{10}$ Nyoman Kutha Ratna, Teori, Metode, dan Teknik Penelitian Sastra, (Yogyakarta: Pustaka Pelajar, 2004), hlm. 53.

${ }^{11}$ Anton Bakker dan Ahmad Charis Zubair, Metode Penelitian Filsafat, (Yogyakarta: Kanisius. 1994), hlm. 109. 


\section{Hasil dan Pembahasan}

\section{Biografi Rabi'ah al-Adawiyah}

Rabi'ah al-Adawiyah adalah seorang sufi perempuan yang pertamakali merepresentasikan mengenai tanda -tanda mahabbah atau cinta murni mistisisme pada pertengahan abad ke delapan, dia berasal dari Bashrah, Rabi'ah al-Adawiyah boleh dibilang sebagai perempuan suci yang Allah takdirkan sebagai orang yang ahli ibadah dan digolongkan dalam golongan para auliya' Allah (para kekasih Allah). ${ }^{12}$

Ajaran tasawuf yang dibawa Rabi'ah itu dikenal dengan istilah al-Mahabbah. Paham ini merupakan kelanjutan dari tingkat kehidupan zuhud yang dikembangkan oleh Hassan al-Basri, yaitu takut dan pengharapan dinaikkan oleh Rabi'ah menjadi zuhud karena cinta. Cinta yang suci murni itu lebih tinggi dari pada takut dan pengharapan. ${ }^{13}$

Rabi'ah al-Adawiyahbanyak mengungkapkan mengenai cinta pada Allah dalam sya'ir-sya'irnya..Rabi'ah al-Adawiyah memaknai cinta sangat dalam, menurutnya, Allah adalah tumpuan mutlak cinta sejati yang tidak bisa diganggu gugat oleh siapa pun, tidak ada ya ng bisa menggantikan hasrat kerinduan dan cinta yang melua-luap selain Allah saja sebagai sandaran jiwanya, kekasihnya, penentram jiwanya, tempat menumpahkan segala keluh kesah segala persolan hidupnya. ${ }^{14}$ Bagi Rabi'ah cinta kepada Allah merupakan satu-satunya pendorong dalam segala aktivitasnya, bukan lagi karena takut siksa neraka atau nikmat surga, hal ini terungkap dalam syair-syairnya. Tiada lain semuanya karena berlandaskan cinta dan yang dicintai. Karena kecintaan itulah menyebabkan ia senantiasa rindu dan pasrah kepada Allah. Sepanjang hidupnya ia tidak pernah berhasrat untuk menikah dan meminta uluran tangan sesamanya. Di dalam jiwanya tidak ada ruang kosong yang tersisa untuk diisi dengan rasa cinta kepada makhluk maupun benci terhadapnya. 15

Untuk mencapai tingkatan yang tinggi, sampai pada tingkat Mahabbah dan makrifat, Rabi'ah menempuh berbagai jalan atau tahap-tahap sebagaimana para sufi lainnya. Martabat yang telah dicapainya, tidak hanya dengan meniru atau mengumpulkan ilmu saja, akan tetapi dengan penggemblengan dan watak. ${ }^{16}$

\section{Biografi Husain Manshur al Hallaj ${ }^{17}$}

\footnotetext{
${ }^{12}$ Rudiyanto SW al-Kedokany, 165 Nafas-Nafas Cinta: Kidung Cinta Rabi'ah alAdawiyah, (Jakarta: RajaGrafindo Persada, 2010), hlm. 35.

${ }^{13}$ Hamka, Tasawuf Perkembangan dan Pemurniannya, (Jakarta: PT Pustaka Panjimas, 1984), hlm. 79.

${ }^{14}$ Rudiyanto SW al-Kedokany, 165 Nafas-Nafas Cinta..., hlm. 33.

${ }^{15}$ Abdul Halim, Cinta Illahi, Studi Perbandingan antara Al-Ghazali dan Rabi'ah alAdawiyah, (Jakarta: Kerjasama Program Pasca Sarjana IAIN Syarif Hidayatullah dengan Program Pasca Sarjana Universitas Indonesia, 1995), hlm. 72.

${ }^{16}$ Sururin, Rabiah Al-Adawiyah Hub Al-Illahi Evolusi Jiwa Manusia Menuju Mahabbah dan Makrifah, (Jakarta,: PT Raja Grafindo Persada, 2002), hlm. 47.

${ }^{17} \mathrm{https}: / /$ maulanusantara.wordpress.com/husain-manshur-al-hallaj-syahid-al-isyqal-ilahi/amp/.
} 
Nama lengkapnya Abu Mughis al-Husein bin Manshur al-Hallaj. Beliau dilahirkan pada tahun $244 \mathrm{H}$ (858 M) di kota Thur kawasan Bidah daerah Fars (Iran Tenggara) tidak jauh dari pantai teluk Persia dan dibesarkan di kota Wasit (Irak) dan Tustar. Dia anak tukang pemilah benang yang miskin. Hallaj kecil dititipkan keduanya kepada Syekh Sahl al Tustari (w.238 H), sufi besar pada zamannya, untuk mengaji kepadanya dan mengabdi kepada Tuhan di masjidnya, memenuhi janji mereka ketika mendamba bertahun kelahirannya. Ketika Hallaj menyapu di mihrab, dia menemukan secarik kertas kewalian gurunya, yang konon, turun dari langit. Diam-diam Hallaj menelannya, mengambil keberkatan. Tak lama, dia menjadi aneh, ia sering bergumam sendiri.

Dalam usia 12 tahun dia hafal al-Qur'an seluruh, dia juga mengaji beragam keilmuan tradisional Islam kepada sejumlah guru di Wasit, sebuah kota dekat Ahwaz. Usai ngaji di kampungnya, dia pergi ke Bagdad, untuk meneruskan mengaji pada sufi otoritatif: Abu al Qasim Al Junaed (w.298 H), Amir al Makki (w. 291) dan guru yang lain. Ketika Hallaj 20 tahun, dia ditahbiskan sebagai guru dalam Tasawuf. Tak lama ke kemudian dia ke Makkah untuk haji. Di kota suci ini, pergulatannya dengan dunia sufisme semakin intens. Otoritasnya di bidang ini semakin menonjol.

Hallaj kembali ke Baghdad, mendiskusikan berbagai problem dan isu krusial sufisme, dengan Syeikh Junaed, Abu Bakar al Syibli dan sejumlah sufi besar lainnya. Dia selalu tak puas. Pikiran-pikirannya semakin radikal, melawan mainstream, tapi semakin matang. Dia lalu kembali ke kampungnya untuk tak berhenti mencari Tuhan dan dia menemukan-Nya di dalam rumah hatinya sendiri. Baju sufi ditanggalkannya dan menggantinya dengan baju tentara, kadang baju robek-lusuh, biar lebih bebas dan tak dikenal saleh. Sesudah itu namanya disebut secara popular sebagai Hallaj al Asrar (Hallaj, sang pemilik rahasia-rahasia). Dari perjalanan ini dia mulai tampil dengan gagasan-gagasan sufismenya yang menggemparkan. Dia sebarkan gagasan itu secara terbuka dan segera mengundang

resistensi dan reaksi kebingungan dan kemarahan publik. Ucapan-ucapan Cintanya kepada Tuhan semakin tak dimengerti halayak. Dia semakin "gila". Dia dicacimaki sebagai tukang sihir dan orang gila. Tetapi sebagian lain melihatnya sebagai pribadi memesona, nyentrik, yang menebarkan keramat dan keberkatan. Dialah Waliyullah, kekasih Tuhan. Al Hallaj tak peduli dengan semuanya. Dia menuliskan dan menggumamkan seluruh kegelisahan dan keriangan batinnya yang meluap-luap itu kapan saja. Setiap malam, ketika senyap, dia mendesahkan elegi yang mengiris nurani.

\section{Representasi Cinta pada Allah dalam syair Rabi'ah al-Adawiyah}

Sebagaimana telah disebutkan di atas bahwaRabi'ah al-Adawiyah adalahsalah satu tokoh sufi yang terkenal dengan pemikiran mengenai mahabbah-nya. Cinta merupakan puncak ajarannya. Rabi'ah al-Adawiyah memaknai cinta pada Allah dengan sangat dalam. Hal tersebut dapat dilihat dalam syair-syairnya. Adapun 
salah satu sya'ir Rabiah al-Adawiyah mengenai cinta pada Allah adalah sebagai berikut: ${ }^{18}$

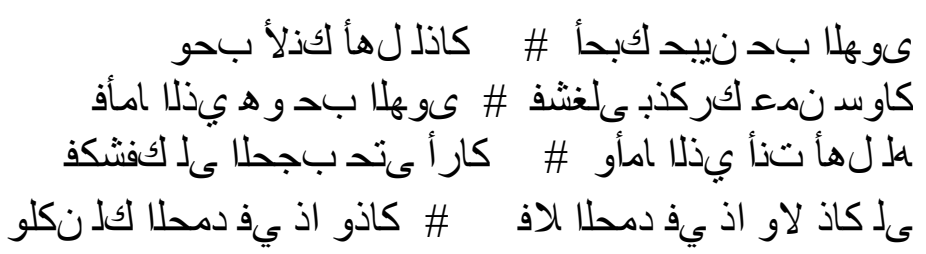

Aku mencintai-Mu dengan dua cinta: cinta karenaperasaan cinta

Dan cinta karena Engkaulah cinta (sebenarnya)

Adapun cinta dengan perasaan cinta itu

Maka aku sibuk mengingat-Mu dengan hal selain(dzat)-Mu

Sedangkan cinta karena Engkaulah cinta

Maka Kau singkap tabir-tabir hingga aku melihat-Mu

Tiadalah pujian untuk cinta yang ini maupun ituuntukku

Tetapi bagi-Mu-lah pujian (untuk) kedua cinta itu

\section{Bait ke-1}

Pada bait pertama, Rabi'ah mengungkapkan dua alasan dalam mencintai Allah, yaitu: pertama, mencintai Allah karena rasa cinta yang timbul di hatinya sebagai seorang manusia, berwujud kerinduan yang alami dirasakannya; kedua, rasa cinta pada Allah yang timbul di hatinya karena Allah itulah sejatinya cinta dan Dzat yang selayaknya dicintai.

Makna yang terdapat dalam bait pertama di atas, bahwa dalam mencintai Allah, Rabi'ah melibatkan dua sisi cinta. Pertama adalah cinta yang bertumpu pada sisi manusiawinya, cinta yang dikenal manusia pada umumnya, cinta yang penuhemosi, cinta yang berlandaskan nafsu perasaan diri saja. Namun, sejalan dengan waktu ia merasakan cinta yang berbeda, cinta yang tidak bisa disamakan dengan cinta yang umumnya dikenal manusia, cinta yang tidak bisa disamakan dengan rasa cinta pada selain Dia, karena ternyata dalam mencintai Allah, hakikatnya adalah karena Dia-lah Dzat yang selayaknya dicintai. Dengan seluruh sifat dan asma-Nya yang indah, maka Dia-lah selayaknnya pemilik cinta yang sesungguhnya, tumpuan sejati cinta para hamba-Nya.

Maka dari bait pertama ini menggambarkan bahwa kedalaman cinta pada Allah yang Rabi'ah rasakan secara utuh adalah bahwa dalam mencintai Allah, tidak bisa hanya dengan perasaan cinta secara cinta manusia saja, akan tetapi cinta pada Allah akan menjadi utuh saat cinta itu bertumpu pada hakikat cintanya, yaitu mencintai Allah karena Dia-lah Sang Pemilik Cinta, yang Maha Mencintai dan selayaknya paling dicintai.

\section{Bait ke-2}

${ }^{18}$ Halim Rofi'ie, Cinta Ilahi: Menurut Al-Ghazali dan Rabi'ah Al-Adawiyah..., hlm. 76. 
Pada bait kedua, mengungkapkan bahwa rasa cinta yang dirasakan Rabi'ah alAdawiyah karena rasa cintanya sendiri sebagai manusia, itu kemudian berimplikasi pada cara mencintai Allah, Rabi'ah mencintai Allah dengan menyibukkan dirinya dengan mengingat selain-Nya, dia mencintai Allah dengan mengingat-ingat makhluk ciptaan-Nya, memperhatikan keberadaan alam ciptaanNya.

Pada bait tersebut tergambar bagaimana jenis cinta yang pertama yang Rabi'ah rasakanitu kemudian berimplikasi pada caranya mencintai Allah. Cara mencintai Allah yang bertumpu pada perasaannya sebagai manusia, tentu akan melahirkan cara-cara mencintai yang juga bersifat manusiawi, dalam arti mencintai dengan terikat oleh hal-hal yang material, karena pada dasarnya manusia selalu terikat dengan hal yang sifatnya materi atau konkret. Sehingga dalam mencintai Allah, Rabi'ah sibuk dengan mengingat selain-Nya, mengingat segala ciptaannya di muka bumi ini, memperhatikan pergantian malam dan siang dengan teratur, itulah cara Rabi'ah mencintai Allah dengan perasaan cintanya sebagai manusia.

Pada jenis cinta yang pertama ini, dalam mencintai Allah dengan menyibukkan diri mengingat pada makhluknya, bertumpu pada hal-hal material, maka itu adalah cara mencintai yang tidak utuh, cinta yang tidak sempurna, karena masih beralasan pada hal-hal selain Dia yang dicintai, yaitu Allah SWT..sehingga kemudian Rabi'ah mengungkapkan bait sya'ir cintanya yang selanjutnya.

\section{Bait ke-3}

Pada bait ketiga, menjelaskan sisi cintanya pada Allah yang kedua, bahwa cinta yang Rabi'ah al-Adawiyah rasakan karena bertumpu pada hakikat cinta itu sendiri, yaitu Allah SWT., maka berimplikasi pada caranya mencintai Allah. Rabi'ah mencintai Allah bukan dengan mengingat makhluk-Nya, akan tetapi Rabi'ah mencintai Allah karena tabir diri-Nya telah tersingkap di hadapan Rabi'ah, sehingga Rabi'ah mencintai Allah karena dia dapat melihat keagungan Allah sebagai Dzat-Nya sendiri.

Pada bait tersebut menggambarkan bagaimana implikasi cinta Rabi'ah alAdawiyah yang kedua, yaitu mencintai Allah karena Allah-lah sejatinya pemilik segala cinta. Gambaran mencintai Allah dengan cinta yang hakiki adalah bahwa saat mencintai Allah dengan cinta yang tidak seperti dikenal oleh manusia, cinta pada Allah tentulah berbeda dengan mencintai manusia. Saat mencintai Allah karena Dzat-Nya sendiri, maka dalam mencintai-Nya pun akan terlepas dari halhal yang bersifat material, tidak terikat oleh hal-hal yag manusiawi.

Berdasarkan hal tersebut, bahwa ketidak-utuhan dalam mencintai Allah dengan cinta yang pertama, kemudian menemukan tumpuan untuk menemukan bagaimana mencintai Allah secara utuh, yaitu di bait ke-3 ini. Bahwa kesempurnaan mencintai Allah bagi Rabi'ah al-Adawiyah adalah saat mencintaiNya tanpa alasan yang di luar diri-Nya, mencintai-Nya tanpa terikat dengan halhal selain-Nya, karena sejatinya cinta adalah Dia, Dzat yang menjadi hakikat dari segala cinta, dan segala cinta yang ada adalah karena rasa cinta pada-Nya.

\section{Bait ke-4}

Pada akhirnya, segala kemuliaan cinta pada Allah yang dirasakan oleh Rabi'ah al-Adawiyah, baik cinta yang dirasakan karena perasaannya sendiri sebagai manusia, ataupun cinta yang dirasakan karena Dzat Allah itu sendiri, seluruhya 
adalah karena Maha Rahman Rahim Allah, karena izin dan bimbingan hidayah Allah yang menurunkan rasa cinta itu di hati Rabi'ah.

Pada bait terakhir di atas, Rabi'ah al -Adawiyah mengembalikan seluruhnya pada hakikatnya yaitu Allah. Rabi'ah menggambarkan bahwa dia mampu merasakan cinta pada Allah, baik dengan perasaan cintanya sendiri ataupun cinta pada Allah karena Dzat Allah itu sendiri, maka seluruh kemuliaan dan ketulusan rasa cinta itu adalah dari Allah, dapat dirasakan karena dengan pertolongan, bimbingan dan izin Allah, sehingga segala pujian adalah untuk Allah, dan hanya milik Allah.

Hal tersebut menunjukkan bahwa semua kebaikan dan kemuliaan adalah datang dari Allah, Rabi'ah sebagai manusia dan makhluk ciptaan Allah, tidak akan mampu merasakan dalamnya cinta di hatinya pada Allah, tanpa Allah yang menghendaki semua itu atas dirinya. Maka makhluk tidak memiliki daya atau kekuatan, selain dengan pertolongan dan kehendak Allah. Maka selayaknya bahwa setiap kebaikan dikembalikan pada Allah, dan segala puji hanyalah milikNya.

Abu Thalib al-Makki dalam mengomentari syair di atas mengatakan, dalam cinta rindu itu, Rabi'ah telah melihat Allah dan mencintai-Nya dengan merenungi esensi kepastian, dan tidak melalui cerita orang lain. Ia telah mendapat kepastian (jaminan) berupa rahmat dan kebaikan Allah kepadanya. Cintanya telah menyatu melalui hubungan pribadi, dan ia telah berada dekat sekali dengan-Nya dan terbang meninggalkan dunia ini serta menyibukkan dirinya hanya dengan-Nya, menanggalkan duniawi kecuali hanya kepada-Nya. Sebelumnya ia masih memiliki nafsu keduniawian, tetapi setelah menatap Allah, ia tanggalkan nafsu-nafsu tersebut dan Dia menjadi keseluruhan di dalam hatinya dan Dia satu-satunya yang ia cintai. Allah telah membebaskan hatinya dari keinginan duniawi, kecuali hanya diri-Nya, dan dengan ini meskipun ia masih belum pantas memiliki cinta itu dan masih belum sesuai untuk dianggap menatap Allah pada akhirnya, hijab tersingkap dan ia berada di tempat yang mulia. Cintanya kepada Allah tidak memerlukan balasan dari-Nya, meskipun ia merasa harus mencintai-Nya. Al-

Makki melanjutkan, bagi Allah, sudah selayaknya Dia menampakkan rahmat-Nya di muka bumi ini karena doa-doa Rabi'ah (yaitu pada saat ia melintasi jalan itu) dan rahmat Allah itu akan tampak juga di akhirat nanti (yaitu pada saat tujuan akhir itu telah dicapainya dan ia akan melihat wajah Allah tanpa ada hijab, berhadap-hadapan). Tak ada lagi pujian yang layak bagi-Nya di sini atau di sana nanti, sebab Allah sendiri yang telah membawanya di antara dua tingkatan itu (dunia dan akhirat). ${ }^{19}$

\section{Representasi Cinta pada Allah dalam syair al-Hallaj}

$$
\begin{aligned}
& \text { نافجلأ عى عو مدلا ىرج لثم } \\
& \text { نايء ن ن انايء عىنيعب } \\
& \text { ناكم لك ريغب ىدذء }
\end{aligned}
$$$$
\text { ىرجت حناوجلاو بلقلا يف تنأ }
$$

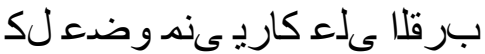$$
\text { كتلثنمت كار أ نأ تقنتثا اذإف }
$$

${ }^{19}$ Margareth Smith, Mistisme Islam dan Kristen Sejarah Awal danPerkembangannya, terj. Amroeni Drajat, (Jakarta: Gaya Media Pratama, 2007), hal. 277. 


$$
\text { اركذ رثكأ كاسنأ ئلأ لا عناسل بيرجي كاذب نكلو ك }
$$

Engkau mengalir dalam hati dan tulang rusuk

Seperti aliran air dikelopak mata

Semua anggota tubuhku melihat-Mu dari dekat

Dengan mata kepalaku terlihat dengan nyata

Jika aku rindu melihat Engkau maka aku membayangkan-Mu

Namun tak dapat berada disemua tempat

Bukan karena aku melupakan-Mu dengan banyak mengenang-Mu

Namun dengan demikian lidahku senantiasa menebut nama-Mu

\section{Bait ke-1}

Pada bait pertama, al-Hallaj mengungkapkan kedalaman cintanya pada Allah pada tahap pertama, yaitu mencintai Allah dengan perasaan yang ada dalam dirinya. Dia menunjukkan bahwa dalam dirinya selalu ada Allah, dirinya tak dapat terlepas dari cintanya pada Allah, hal tersebut dia gambarkan dengan menyerupakan Allah sebagai sesuatu yang selalu mengalir dalam hati dan tulang rusuknya. Al-Hallaj juga menunjukkan bahwa dia senantiasa merasakan kehadiran dan kedekatannya dengan Allah, seperti aliran air di kelopak mata, terasa ada dan sangat dekat. Begitulah al-Hallaj menggambarkan cinta pada Allah berwujud abadi dalam diri seorang hamba, hingga tidak ada celah kosong dalam dirinya dari kecintaannya pada Allah. Dan dengan cinta itu, seorang hamba merasakan Allah sangat nyata dan sangat dekat. Maka dari bait pertama syair al-Hallaj tersebut menunjukkan dua wujud kecintaan pada Allah, yaitu kedawaman cinta dan merasakan kedekatan Allah secara nyata.

\section{Bait ke-2}

Pada bait kedua, al-Hallaj menggambarkan bahwa kecintaannya sampai membuat dia dan seluruh anggota tubuhnya melihat Allah secara nyata. Hal ini merupakan tahapan yang memperkuat wujud kecintaannya kepada Allah dari ungkapan pada bait yang pertama. Setelah al-Hallaj merasakan keberadaan Allah dan kedekatan Allah selalu dalam dirinya, kemudian pada bait kedua dia menunjukkan bahwa kecintaannya sampai membuatnya melihat Allah secara nyata. Tingkatan cinta pada Allah yang tidak biasa dan tidak dirasakan oleh manusia secara umum. Hal ini menunjukkan tahapan kedalaman cinta kepada Allah yang sangat mendalam.

\section{Bait ke-3}

Pada bait ketiga, al-Hallaj menunjukkan bahwa cinta pada Allah juga berwujud kerinduan. Dan yang dilakukan saat merindukan Allah, dia membayangkan Allah. Hal ini menunjukkan bukti kedalaman cintanya pada Allah sampai tahap puncak, 
di mana Allah tidak hanya terasa dekat di dalam dirinya, tetapi Allah sangat nyata di pandangan al-Hallaj, hingga saat rindu dia membayangkan Allah.

\section{Bait ke-4}

Pada bait keempat, al-Hallaj menyampaikan hakikat dari mengingat Allah dan perwujudannya dalam perilaku nyata. Hakikat dari mengingat Allah ditunjukkan al-Hallaj dengan permainan logika bahasa yang digunakan di bait tersebut, bahwa dia mengingat Allah, bukan berarti karena dia terlupa pada Allah, karena secara logika, saat seseorang mengingat sesuatu berarti dia telah melupakannya. Dalam bait syair al-Hallaj tersebut, dia menunjukkan bukti kerinduan pada Allah dengan mengingat-Nya secara dawam, tidak ada celah terlupa pada Allah yang dicintainya. Sehingga mengimgat Allah itu bukanlah berarti dia terlupa pada-Nya, akan tetapi agar kerinduannya itu berwujud pada aktivitas nyata, yaitu lisan yang selalu bergumam menyebut nama Allah. Jelaslah pada bait terakhir ini, al-Hallaj menunjukkan bukti keabadian rindu pada Allah adalah dengan mengingatnya, dan bukti dari mengingatnya berwujud pada lisan yang senantiasa berdzikir.

\section{Persamaan Representasi Cinta pada Allah dalam syair Rabi'ah al- Adawiyah dengan syair al-Hallaj}

Persamaan yang terdapat dalam syair cinta Rabi'ah al-Adawiyah dan syair alHallaj terletak pada makna atau pikiran pokok dari kedua syair tersebut. Dalam kedua syair tersebut digambarkan bahwa dalam mencintai Allah, kedua penyair tersebut -yang juga merupakan seorang sufi- merasakan kedalaman cinta pada Allah dengan dua sisi cinta. Pertama, cinta pada Allah yang lahir atau muncul dalam diri sendiri, yaitu cinta yang hadir secara alami dalam diri seorang hamba. Cinta ini merupakan tahap pertama dalam mencintai Allah. Setelah merasakan cinta yang alami hadir dalam diri, pada tahap selanjutnya kedua penyair tersebut menggambarkan bagaimana cinta pada Allah sampai pada puncaknya, yaitu melihat Allah secara nyata. Cinta yang kedua ini merupakan puncak dari kedalaman cinta seseorang terhadap Allah, sehingga terbuka hijab antara dirinya dengan Allah. Ini merupakan kenikmatan cinta pada Allah yang hakiki, yang tidak semua orang dapat meraih tingkatan cinta ini.

Jadi dapat disimpulkan bahwa kedua penyair tersebut ingin menggambarkan bahwa representasi cinta pada Allah itu mengalir dalam diri seseorang, dari tahap keberadaan cinta secara manusiawi, yaitu tingkat cinta yang umum, sampai mencapai puncak cinta terdalam yaitu merasakan melihat Allah secara nyata, ini cinta yang khusus dan tidak biasa dirasakan oleh umumnya manusia.

\section{Perbedaan Representasi Cinta pada Allah dalam syair Rabi'ah al- Adawiyah dengan syair al-Hallaj}

Perbedaan yang terdapat dalam syair cinta Rabi'ah al-Adawiyah dan syair alHallaj terletak pada mbeberapa hal berikut: 
Pertama, implikasi dari cinta pada Allah pada tahap pertama, yaitu cinta karena perasaan cinta yang hadir dalam diri, antara kedua penyair tersebut digambarkan berbeda. Pada syair Rabi'ah al-Adawiyah, cinta karena perasaan cinta itu dirasakan dengan cara mengingat selain Allah, merenungi kehidupan, dan mentafakuri kebesaran Allah yang terwujud dalam hal-hal material dunia. Sedangkan dalam syair al-Hallaj, cinta pada allah karena perasaan cinta yang timbul dalam diri itu digambarkan dengan dia mengingat Allah dengan secara langsung, tanpa terkait dengan selain-Nya, secara alami merasakan kedekatan Allah dan membayangkan-Nya, juga dengan menyebut-nyebut nama-Nya.

Kedua, pengungkapan mengenai puncak kedalaman cinta pada Allah yaitu merasakan melihat Allah secara nyata, dalam kedua syair tersebut disajikan dalam gaya bahasa yang berbeda. Dalam syair Rabi'ah al-Adawiyah disebutkan bahwa Allah yang membukakan hijab-Nya, sehingga Rabi'ah dapat melihat Allah. Seperti dalam bait كار أ ىتد بجحلا ىل كفنك. Dalam bait tersebut, Allah menduduki posisi sebagai fa'il (pelaku) yang membukakan hijabnya untuk Rabi'ah. Berbeda dengan syair al-Hallaj, yang menjadi pelaku adalah penyair itu sendiri, yaitu seluruh anggota tubuhnya dapat melihat Allah. Seperti dalam bait كاري sنم وضد لك . برقلا علء Dalam bait tersebut, yang menjadi fa'il adalah penyair (anggota badan penyair), dan Allah menduduki posisi sebagai maf'ul (objek).

Dari pemaparan di atas, jelas bagaimana perbedaan antara syair cinta Rabi'ah al-Adawiyah dengan syair cinta al-Hallaj, baik perbedaan dari segi pemaknaan terhadap representasi cinta pada Allah maupun perbedaan dalam gaya penyajiannya.

\section{Penutup}

Rabi'ah al-Adawiyah dan al-Hallaj merupakan dua tokoh sufi yang sama-sama memiliki pengungkapan tersendiri mengenai konsep cinta pada Allah yang tertuang dalam syair-syairnya. Setelah dilakukan analisis terhadap syair cinta dari kedua tokoh sufi tersebut, dapat disimpulkan bahwa dalam kedua syair dari dua tokoh tersebut memiliki keterkaitan persamaan, juga perbedaan. Persamaan antara kedua syair tersebut terdapat pada makna pokok keduanya, yaitu bahwa representasi cinta pada Allah itu mengalir dalam diri seseorang, dari tahap keberadaan perasaan cinta secara manusiawi, yaitu tingkat cinta yang umum, sampai mencapai puncak cinta terdalam yaitu merasakan melihat Allah secara nyata. Adapun perbedaan antara keduanya terletak pada segi pemaknaan terhadap wujud cinta tahap yang pertama, yang dalam syair Rabi'ah cinta pada Allah itu terwujud dengan mengingat dan mentafakuri selain-Nya, adapun dalam syair alHallaj cinta itu berwujud dengan secara langsung mengingat-Nya, tanpa perantara selain-Nya. Selain itu, perbedaan antara kedua syair tersebut juga terletak pada gaya penyajiannya. 


\section{Daftar Pustaka}

Al-Ghazali. t.t. Ihya 'Ulum ad-Din. Juz IV. Indonesia: Dar Ihya al-Kutub al'Arabiyyah.

Al-Kalabazi. 1990. Ajaran Kaum Sufi: terj. Rahmani Astuti. Bandung: Mizan.

Al-Kedokany, Rudiyanto SW. 2010. 165 Nafas-Nafas Cinta: Kidung Cinta Rabi'ah al-Adawiyah. Jakarta: RajaGrafindo Persada.

Al-Maraghi, Ahmad Mustafa. 1962. Tafsir al-Maraghi. juz 1. Mesir: Mustafa alBabi al-Halabi wa Auladuh.

Bakker, Anton dan Ahmad Charis Zubair. 1994. Metode Penelitian Filsafat. Yogyakarta: Kanisius.

Endraswara, Suwardi. 2010. Sastra Bandingan: Metode, Teori, dan aplikasi. Yogyakarta: Universitas Negeri Yogyakarta.

Endraswara,Suwardi. 2011.Metodologi Penelitian Sastra Bandingan. Jakarta: Bukupop.

Halim,Abdul. 1995. Cinta Illahi, Studi Perbandingan antara Al-Ghazali dan Rabi'ah al-Adawiyah. Jakarta: Kerjasama Program Pasca Sarjana IAIN Syarif Hidayatullah dengan Program Pasca Sarjana Universitas Indonesia.

Hamka. 1984. Tasawuf Perkembangan dan Pemurniannya. Jakarta: PT Pustaka Panjimas.

Https://maulanusantara.wordpress.com/husain-manshur-al-hallaj-syahid-alisyq-al-ilahi/amp/.

Ma'luf, Louis. 1973. al-Munjid fi al-Lughah wa al-A 'lam. Beirut: Dar al-Masyriq.

Muhdar, Yunus Ali\& Bey Arifin. 1983. Sejarah Kesusastraan Arab. Surabaya : PT Bina Ilmu.

Ratna, Nyoman Kutha. 2004. Teori, Metode, dan Teknik Penelitian Sastra. Yogyakarta: Pustaka Pelajar.

Rofi' ie, Halim. 2000. Cinta Ilahi: Menurut Al-Ghazali dan Rabi'ah Al-Adawiyah. Jakarta: PT.RajaGrafindo Persada.

Smith Margareth. 2007. Mistisme Islam dan Kristen Sejarah Awal danPerkembangannya, terj. Amroeni Drajat. Jakarta: Gaya Media Pratama.

Sururin. 2002. Rabiah Al-Adawiyah Hub Al-Illahi Evolusi Jiwa Manusia Menuju Mahabbah dan Makrifah. Jakarta,: PT Raja Grafindo Persada. 